\title{
11 Breaking the Vicious Circle: Financial Policies for High-Quality Saving
}

This book argues that Latin America and the Caribbean suffers from two interrelated problems: saving is low, and those meager savings are used inefficiently. The two problems are connected and reinforced by the financial system-the set of institutions through which resources are channeled from savers to investors in the economy.

Figure 11.1 traces these connections. To start with, low saving in Latin America means that only a small flow of funds becomes available to firms and individuals that need to invest. This limited supply of loanable funds, in turn, limits the growth of the financial industry, resulting in high unit costs to channel funds between lenders and borrowers (the process of financial intermediation). High costs compound other distortions in financial markets, such as the poor quality of credit information and weak protection of property rights. As a result, the available savings in the economy are misallocated: for example, the firms that receive credit from banks are not necessarily the most productive ones, or the ones with the greatest productive potential, but rather those that can pledge collateral. The inefficient use of resources in the economy, in turn, is a main determinant of the region's low productivity (Pagés, 2010). Finally, low productivity is the other side of the coin of low returns to investment and saving (See Chapter 10). Not surprisingly, given the low returns to saving that prevail in the region, savings-and the financial intermediation of available savings-are also low.

The circle ends where it began: Latin America and the Caribbean is a region of low saving with undeveloped financial systems. Breaking this vicious circle requires concerted policy actions to improve 
Figure 11.1 The Vicious Circle of Low Saving and Inefficient Financial Intermediation

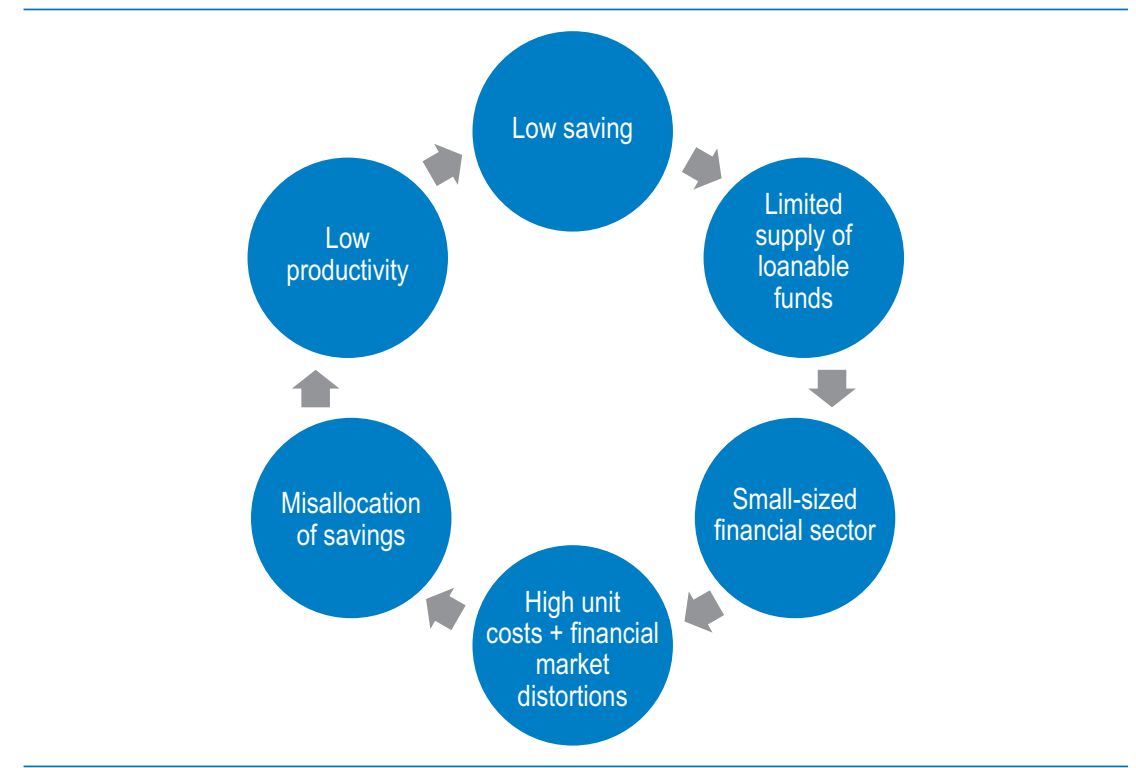

Source: Authors' elaboration.

financial intermediation. This chapter discusses two policy avenues that can help break the circle: (1) reducing financial market frictions to improve the efficiency of intermediation; and (2) encouraging more extensive use of formal financial saving instruments to reduce unit costs of operation.

\section{Toward a Well-Oiled Financial Machine}

In an ideal world with frictionless, competitive financial markets, resources flow toward the most productive investment projects, and the returns of these projects are reflected in the interest rate paid to savers. That is, ideally, developed and competitive financial markets lead to high returns to capital and low interest rate spreads, which translate into high returns for savers. Instead, the low productivity of capital ${ }^{1}$ and the very high interest rate margins between what is charged to lenders and what depositors receive illustrate how far the region is from such an ideal world (see Figure 11.2). ${ }^{2}$ Financial systems across the region do not intermediate savings efficiently; on the contrary, these financial systems are small and fragmented between formal and informal institutions (see Chapter 3 ). 
Figure 11.2 The Spread between Lending and Deposits by Region, 2006-13

Average

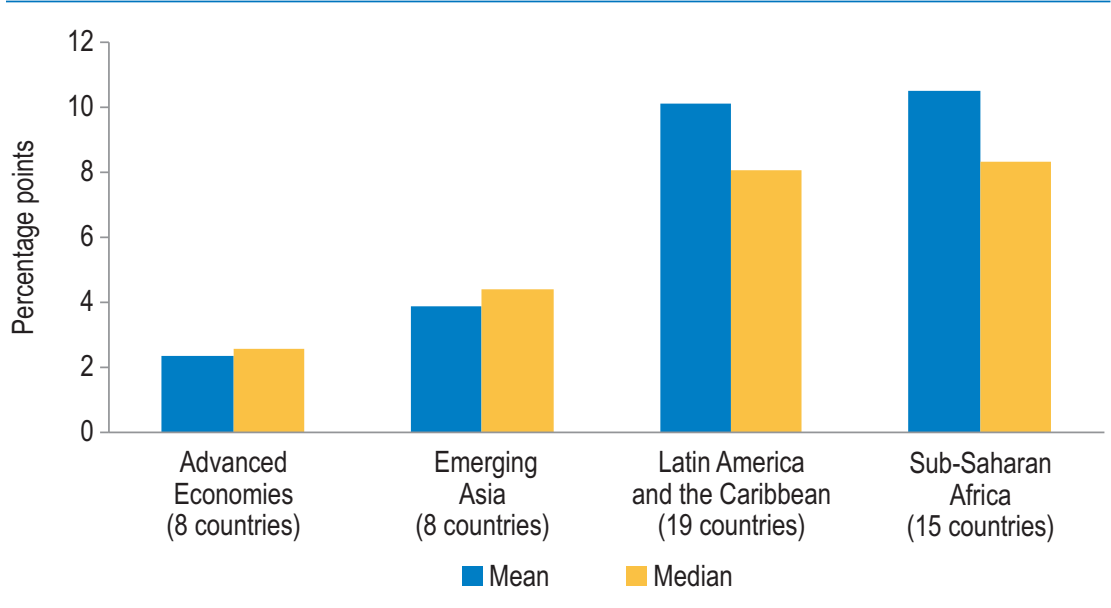

Source: Authors' calculations based on World Bank Global Financial Development Database.

Note: Interest rate spread is the interest rate charged by banks on loans to private sector customers minus the interest rate paid by commercial or similar banks for demand, time, or savings deposits. The terms and conditions attached to these rates differ by country, however, limiting their comparability. See endnote 3 of chapter 2 for the list of countries in each country group.

Financial market distortions and low productivity are intertwined because financial frictions typically undermine the efficient allocation of savings. Misallocation of resources suppresses productivity in the region to about half its potential (Pagés, 2010). If productivity were higher, not only would accumulated savings be used more efficiently, but savings would accumulate more quickly in response to the higher returns prompted by the productivity boost.

At least two types of financial frictions are common in the region and reduce productivity growth. First, financial intermediaries lack good quality information about potential borrowers. With little information upon which to base their decisions, lenders are essentially flying blind; thus, they charge more to cover their risks and raise the margins of financial intermediation. As problems of asymmetric information can divert savings from their most productive uses, reforms that improve information sharing should enhance resource allocation and efficiency. While the region has made good progress in this respect-especially in extending the coverage of credit bureaus - the quality and timeliness of the information available through such bureaus is relatively low in some countries. ${ }^{3}$ While credit information is abundant in some countries, it is scarce in others because the legal environment does not favor the storage and 
exchange of this valuable resource (see Frisancho, 2012). On average the regulatory framework (i.e., rules affecting the scope, accessibility, and quality of credit information available through public or private credit registries) is less conducive to information sharing in Latin America and the Caribbean than in other regions of the world (see Table 11.1).

A second constraint to financial market development and productivity growth in the region relates to the cost of enforcing financial contracts. For financial relationships to thrive, the obligations of each party need to be explicit, and an impartial enforcing agent must be ready to act if needed. Unfortunately, the effective protection of property rights in financial contracts in the region is weak. Column 2 in Table 11.1 illustrates how Latin America and the Caribbean lags behind Advanced Economies and other emerging market countries in the enforcement of legal rights. This raises the cost of financial intermediation in the region. It also feeds mistrust in the financial system because the weak protection of property rights affects both creditors and debtors. ${ }^{4}$ If assets must be pledged as collateral to signal creditworthiness to deal with enforcement problems or information gaps, wealthy but unproductive entrepreneurs may gain access to finance, while poor but productive ones may remain excluded from or underserved by credit markets (see Buera, Kaboski, and Shin, 2011).

To address the underlying distortions, regulatory and institutional reforms are necessary. Several successful reforms have been launched in the region. Bankruptcy reforms in Brazil (2004-05), Colombia (2011), and more recently Chile (2014) appear to be reducing the costs of

Table 11.1 Institutional Credit Market Indicators, Average 2014-2016

\begin{tabular}{lcc}
\hline Region & $\begin{array}{c}\text { Depth of credit information } \\
\text { index } \mathbf{~}^{\mathbf{0}-8)}\end{array}$ & $\begin{array}{c}\text { Strength of legal rights index } \\
\mathbf{( 0 - 1 2 )}\end{array}$ \\
\hline Latin America and the Caribbean & 5.8 & 4.4 \\
Advanced economies & 6.7 & 6.1 \\
Other emerging countries & 6.4 & 5.0 \\
\hline
\end{tabular}

Source: Authors' calculations based on World Bank (2016).

a Depth of credit information index measures rules affecting the scope, accessibility, and quality of credit information available through public or private credit registries. The index ranges from 0 to 8 , with higher values indicating the availability of more credit information, from either a public registry or a private bureau, to facilitate lending decisions.

b Strength of legal rights index measures the degree to which collateral and bankruptcy laws protect the rights of borrowers and lenders and thus facilitate lending. The index ranges from 0 to 12 , with higher scores indicating that these laws are better designed to expand access to credit.

See endnote 3 of chapter 2 for the list of countries in advanced economies and Latin America and the Caribbean. Other emerging economies includes countries from emerging Asia and Sub-Saharan Africa. 
enforcing financial contracts. At least in the case of Brazil, reforms have increased access to credit, especially for smaller firms (Araujo, Ferreira, and Funchal, 2012). Likewise, the recent introduction of collateral registries for movable assets in some countries aims to break the link between wealth and access to finance because they enable working capital and some forms of firm income to be pledged as collateral. In 2006, Peru introduced a law governing guarantees for moveable collateral, and Colombia introduced a similar law in 2013-14. Such policies have helped firms-especially smaller and younger ones-access bank financing under better terms (Love, Martínez Pería and Singh, 2013).

The high fixed costs that characterize financial markets create additional barriers to efficient financial intermediation. High fixed costs create natural incentives for industry concentration, which may lead to uncompetitive practices. While there is plenty of evidence of consolidation in the financial industry in Latin America over the past few decades, there is no compelling evidence that such consolidation or the subsequent increase in concentration has reduced competition (Gelos and Roldós 2004; IDB, 2004; Levy Yeyati and Micco, 2007). If anything, standard measures of market power show that, at least in some countries, market power in loan and deposit markets has fallen over time (Williams, 2012). On the other hand, concentration in the banking industry does appear to impair cost-efficiency (Tabak, Fazio, and Cajueiro, 2011). Such inefficiencies can persist only if various factors prevent additional suppliers from entering the market. Chapter 3 discussed how the combination of high fixed costs and income inequality may limit the size of the financial system in Latin America and the Caribbean because banks naturally locate only in areas where enough customers can afford service costs. One way to weaken the link between high fixed costs of operation and industry concentration is to expand the customer base. More customers would help reduce the unit costs of operations, making it more profitable for other financial institutions to enter the industry.

\section{Broadening the Base}

Savings in the region are channeled through a variety of formal and informal saving vehicles (see Chapter 3). Given this variety, traditional financial inclusion efforts have focused on access: opening bank accounts for the unbanked. This is a necessary first step, but is not enough to encourage formal (financial) saving. 
About 55 percent of the adult population still do not own accounts in formal financial institutions. Why not? According to the 2014 Global Findex Database (World Bank, 2014b), many people say such accounts are too expensive, require too much documentation to open, or are in a financial system they do not trust (see Figure 11.3).

Among people who already own an account, only 31 percent use it to deposit some of their savings, and only 26 percent use it to deposit all of their savings. Why don't people save more through the financial system? Limited physical coverage of banking networks, lack of trust in banks, and high service fees are important constraints to save formally (see Chapter 9). These factors act as pecuniary and nonpecuniary costs that reduce the effective returns to formal saving. With limited returns, no wonder savers shy away from the formal financial system as a saving vehicle. How can these problems be resolved?

\section{Reducing Service Costs}

Financial institutions pass the high average (unit) costs of operating on to their customers, and thus reduce the effective returns that savers receive. In the financial services industry, the scale of operation matters:

Figure 11.3 Reasons Why People Do Not Have a Formal Bank Account, by Region, 2014

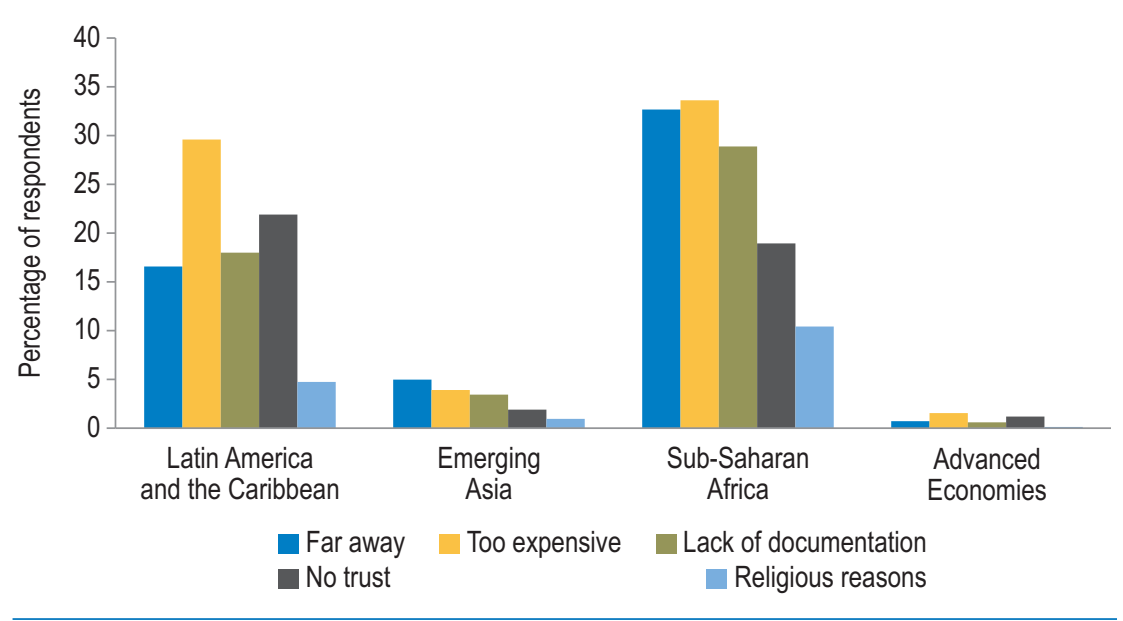

Source: Authors' calculations based on World Bank (2014b).

Note: Bars show percentage of respondents who do not have an account at a financial institution and why. Percentages add up to more than 100 percent in some regions because some respondents gave more than one reason. See endnote 3 of chapter 2 for the list of countries in each country group. 
if suppliers of financial services can spread fixed costs (for physical branches, reserves needed to meet regulatory capital requirements, and so on) over a greater volume of users, unit costs fall. ${ }^{5}$

Currently, only high-income households can afford the high unit service costs of financial services in the region. Excluding a large bloc of potential customers reinforces the "smallness" problem, creating a vicious circle of small customer base, high unit costs, and financial exclusion.

Traditionally, governments around the world have sought to expand the user base of financial services by simply letting demand drive the growth of the financial system. More recently, however, governmentsparticularly those in the developing world-have tried to incorporate potential users of financial services, by channeling large transactional markets, such as government transfers, through the formal financial system.

These strategies may have been successful at increasing ownership of formal saving instruments. Ownership of a formal saving account increased to 45 percent of the region's adult population in 2014 from 34 percent in 2011-a 33 percent increase (World Bank's Global Findex Database). Account ownership increased more in Latin America and the Caribbean than in any other region in the world (see Figure 11.4).

Figure 11.4 Penetration of Formal Savings Accounts, 2011 vs. 2014

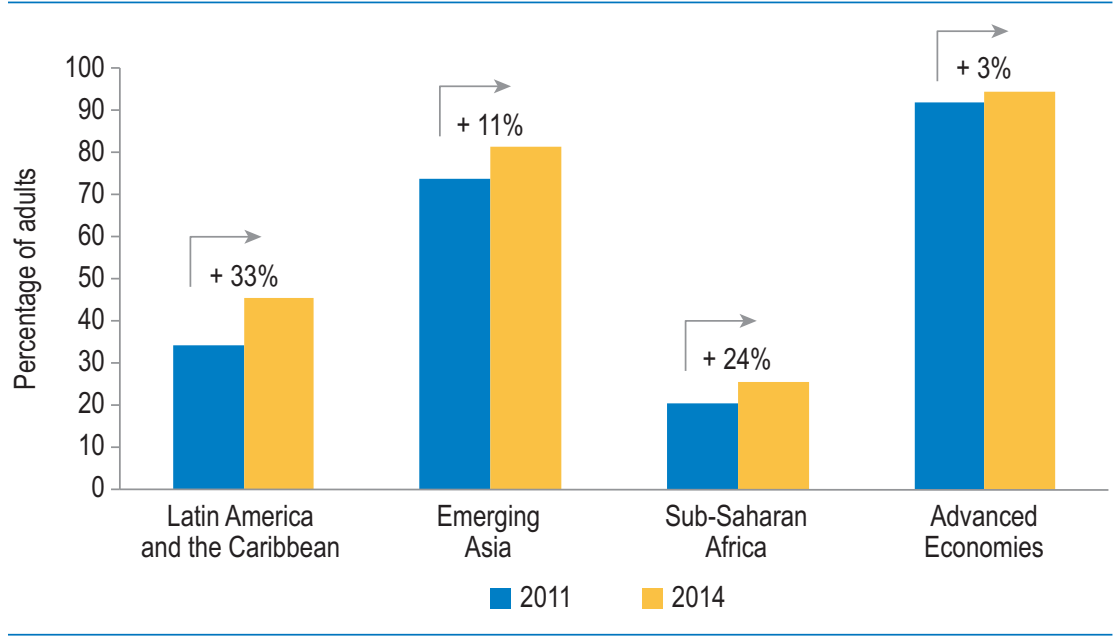

Source: Authors' calculations based on World Bank Findex Database.

Note: Account penetration is the percentage of respondents older than 15 years of age who had an account at a financial institution. See endnote 3 of chapter 2 for the list of countries in each country group. Data available only for 2011 for Paraguay, Trinidad and Tobago, Central African Republic, Comoros, Gabon, Lesotho, Liberia and Swaziland and only for 2014 for Belize, Norway, Switzerland, Ethiopia and Namibia. 
Efforts to expand the customer base can help reduce unit costs, which in turn may encourage more saving. Quasi-experimental evidence demonstrates a causal effect of financial access on saving behavior. For example, people who received their conditional cash transfers (CCTs) in Mexico as a deposit to their bank account increased their total savings by 60 percent, on average, compared to those who received transfers in cash (Ubfal, 2013). This increase in total savings-which included formal and informal instruments-was driven mainly by higher formal savings.

Despite considerable effort to increase financial inclusion, there is still room for improvement on several fronts. On the one hand, Latin America and the Caribbean still has the world's lowest fraction of government transfers paid through formal financial instruments (Figure 11.5). Countries like Bolivia, El Salvador, and Jamaica still have a long way to go to meet even the regional average.

On the other hand, most beneficiaries of social programs in the region who are paid through bank accounts withdraw the money all at once, whether they need the money then or not. This percentage is higher than in other regions. To some extent, this practice may be due to design problems and misinformation. For example, in 2009, Colombia's CCT program, Familias en Acción, began paying beneficiaries

\section{Figure 11.5 Government Transfers Paid through the Financial System}

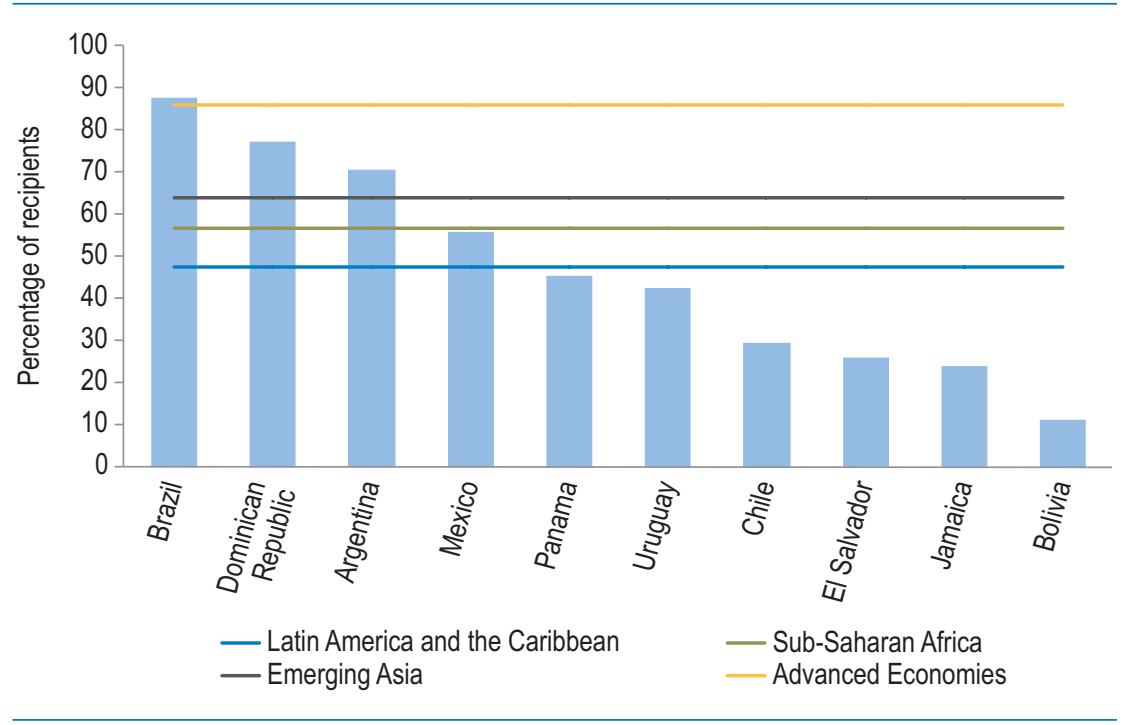

Source: Authors' calculations based on World Bank (2014b).

Note: Variable denotes the percentage of transfer recipients older than 15 years who received government transfers into an account at a financial institution or card in the past 12 months. See endnote 3 of chapter 2 for the list of countries in each country group. 
through basic saving accounts at a state-owned bank. According to data from the government agency in charge of promoting financial access, Banca de Oportunidades, over 90 percent of beneficiaries were receiving the transfers through an account at the state-owned bank by 2012. Yet, over 40 percent of beneficiaries in Bogotá, the main urban center, thought their subsidy money was at risk if left in the bank account (when it really was not). Similarly, many beneficiaries did not know that the bank account used to deposit the CCT did not have a maintenance fee, and most of the recipients did not know that the accounts paid them interest (Maldonado and Tejerina, 2010). In Brazil, most beneficiaries of social programs receive transfers through a limited purpose instrument (electronic card), which as of 2012 required them to withdraw the funds within 60 days of receiving them.

These examples suggest that providing more information to recipients about how bank accounts work and paying attention to program design can help overcome the tendency to withdraw all the funds at once. This would help beneficiaries move a step closer to using the bank accounts for saving rather than for purely transactional purposes.

\section{Keeping it Simple}

Governments across the region have encouraged the financial industry to design and offer saving instruments with a varying mix of functions, costs, and requirements to make them more attractive. Simplified versions of the traditional saving account (sometimes called simplified accounts or basic accounts) are becoming increasingly popular. While the specific characteristics vary from one country to another, three features distinguish these instruments: they provide limited services, including ceilings on balances and transactions; financial institutions charge low (or no) fees and require low (or no) minimum balances; and they require less documentation than traditional accounts.

Many regulators in Latin America have embraced the effort to popularize saving products along these lines. Before implementing further policies to directly influence the features and price of saving products, policymakers should have a clear diagnosis of why innovation and cost reduction have not already taken place. If the problem is that these simplified products are not profitable to banks, for example, then mandating commercial banks to supply them would require public subsidies. Without the subsidies, commercial banks could try to compensate for 
the losses by either making other financial products more expensive or by making it more difficult for potential clients to open the simplified accounts. Alternatively, if the problem is bad regulation or red tape, regulatory reforms would be needed.

The specific case in each country depends on country-specific circumstances. All in all, Latin America and the Caribbean still lags behind other regions in terms of the ease with which financial institutions can offer saving products, and potential customers face more requirements to open bank accounts. According to the Economist Intelligence Unit's Global Microscope, Latin America and the Caribbean as a region on average fares worse than East Asia and Sub-Saharan Africa in these two areas, although a great deal of variation exists across countries. ${ }^{6}$

Mexico is at the forefront of efforts in the region to introduce simplified accounts. In 2011, Mexico introduced a tiered system for the requirements and costs of opening and using bank accounts. Customers with relatively limited saving and transaction needs (in volume) need not go to the branch or provide any form of identification to open an account. Importantly, the system complies with anti-money laundering principles. Within two years, the number of simplified accounts in commercial banks reached 12 million (Faz, 2013). Other countries in the region are following suit; for instance, in 2015 Costa Rica introduced a three-tiered system of accounts whose costs and requirements are proportional to the balances and transactions permitted.

Despite their potential, simpler accounts per se may not be enough to encourage more financial saving. The obstacles that impede ownership of formal saving instruments may be quite different from those that constrain their use as saving vehicles. Furthermore, in some cases, simplified saving products may not be profitable; financial institutions will find it worthwhile to promote them only if they foresee users "graduating" to more complex financial products.

\section{Fostering a Culture of Saving}

Despite the increase in the number of bank accounts across the region in the past decade, the increase in the percentage of people who claim to save through formal financial institutions has been more modest. Saving through formal accounts rose to 16.4 percent of adults in 2014 from 13.9 percent in 2011 (Figure 11.6), an 18 percent increase, according to the World Bank's FINDEX Database. Still, despite the increase, the 
Figure 11.6 Saving through Formal Accounts, 2011 vs. 2014

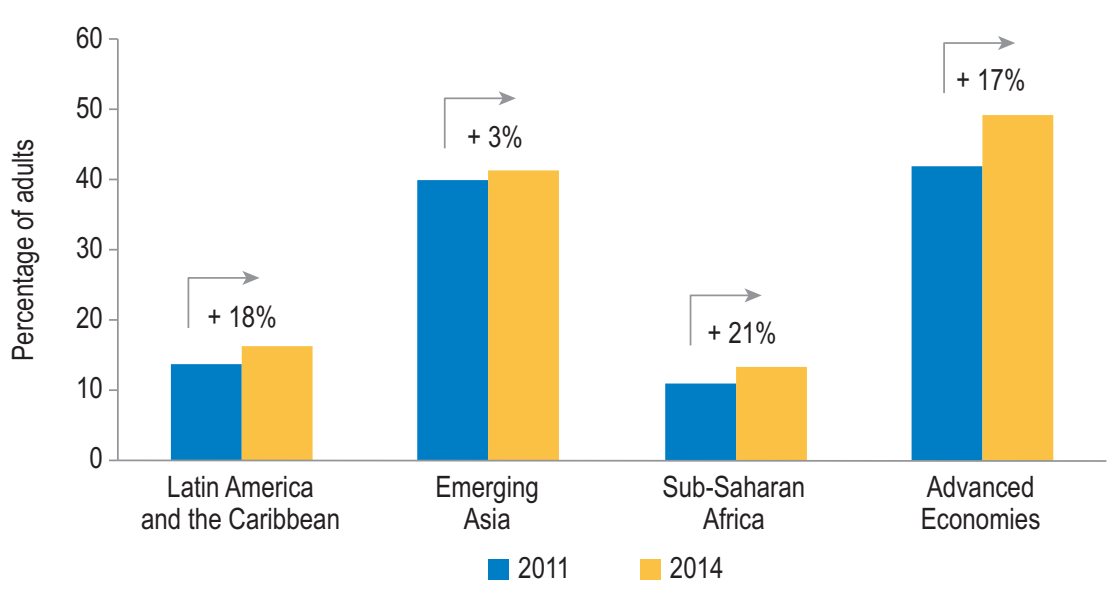

Source: Authors' calculations based on World Bank (2014b).

Note: Measured as the percentage of respondents older than 15 years who saved at a financial institution in the past 12 months.

See endnote 3 of chapter 2 for the list of countries in each country group, restricted here depending on data availability. Data available only for 2011 for Paraguay, Trinidad and Tobago, Central African Republic, Comoros, Gabon, Lesotho, Liberia and Swaziland and only for 2014 for Belize, Norway, Switzerland, Ethiopia and Namibia.

region lags behind Emerging Asia and Advanced Economies, and is only slightly better-off than Sub-Saharan Africa.

More can be done to encourage financial saving by leveraging the government's efforts to expand financial inclusion. Given that lack of trust in banks is a problem in the region, the accounts used to deliver government transfers can be complemented with tools to build people's confidence in the system. As discussed in Chapter 9, lack of trust is sometimes linked to misinformation. For example, to the extent that mistrust reflects potential customers' belief that balances can disappear if the money is not withdrawn, then tools that allow customers to consult balances frequently and free of charge, such as debit cards or other electronic means, can help build user confidence over time.

Experimental evidence shows that people save more after they gain confidence in the system. Bachas, Gertler, Higgins and Seira (2015) study a sample of Oportunidades-Progresa beneficiaries who received a debit card along with their bank account in 2009-11. Beneficiaries could check their account balances as frequently as they wanted, free of charge. Over time, beneficiaries consulted their balances less and made fewer withdrawals. One year after receiving the "treatment" debit card, beneficiaries had reduced consumption and increased formal saving by 
similar amounts (meaning that they channeled all the new saving to formal saving). With less cash in hand, the beneficiaries consumed fewer temptation goods (such as alcohol and tobacco), further reinforcing the increase in saving.

Delivering social transfers through term-saving instruments can help overcome behavioral and social saving constraints. For instance, policymakers in Colombia offered beneficiaries of conditional cash transfers the option to set aside a fraction of the transfer in a term deposit, which they could withdraw after a certain period of time. Households that were offered the fixed-term instrument saved more and invested more in health and education than those who received transfers through a standard deposit account (Barrera-Osorio et al., 2011).

Financial education is also important. Thanks to financial education, combined with delivery of government transfers through bank accounts, beneficiaries of Familias en Accion in Colombia saved more (Núñez Méndez et al., 2012). Similarly, in 2009, Peru started paying government transfers through formal accounts at the state-owned Banco de la Nación. From the beginning, the strategy included a financial education module that assured savers that balances left in the bank account were not at risk. The fraction of beneficiaries with low balances fell from close to 80 percent to less than 10 percent after one year (Trivelli, Montenegro, and Gutiérrez, 2011). A recent impact evaluation of the program (Boyd and Aldana, 2015) finds that financial education has a positive and sizable impact on the probability of saving, and on the probability of saving formally in a nearby bank. The program also helped to formalize saving as beneficiaries gradually transferred their informal savings to the bank account provided by the conditional cash transfer program (Rosen, 2010).

International remittances channeled by migrant workers to their home countries represent another sizable transactional market that remains largely outside the formal financial system. Although every dollar of remittances must, at some point, go through the financial system of the home country, this connection may be limited to the money transfer operator and the bank that carries out the currency conversion. Intermediating remittances through the formal financial system can bolster economic efficiency and individual welfare through various channels. To begin with, the sheer size of remittance flows presents an opportunity to increase the volume of resources and transactions administered by local financial systems, thereby helping to lower unit service costs.?. 
Another important feature of remittances is that they are spaced out in intervals, and arrive in sizable sums (they are "lumpy"). This pattern creates an inherent demand for savings. Researchers estimate that about 20 percent of remittances in developing countries are used for saving or investment. Furthermore, remittances are the point of entry for many remitters and their families to the formal financial system. Financial intermediaries can use remittances as a stepping stone to identify other sources of income for their new customers, which in turn can induce them to increase their lending to customers.

Innovative products and channels have considerable potential to turn remittances into financial saving. Commercial banks in El Salvador have been particularly keen on reducing transaction costs and offering flexible ways to send and collect remittances. Experimental evidence from El Salvador shows that giving remitters greater control over the accounts has the potential to increase savings by over 50 percent (Ashraf et al., 2015).

Greater control by migrants over savings accounts in their home countries can increase both the take-up rates and balances in savings accounts. In a randomized field experiment conducted by Ashraf et al., (2015), Salvadoran migrants in the Washington, DC area were assigned to different savings account options in El Salvador, or received no offer of any new financial product in the comparison group. Each option varied the degree of control participants could exert on the new accounts that were offered at Salvadorian Banks.

The results provide evidence that migrants value and take advantage of opportunities to exert control over savings in their home country. Migrants were much more likely to open savings accounts in El Salvador, and accumulate more savings at the new accounts, if they were assigned to the option offering the greatest degree of monitoring and control. The average savings in a 12-month period increased from US\$186 in the comparison group to US $\$ 282$ in accounts opened in the migrant's own name. The evidence suggests that these numbers represented increases in total savings rather than shifts in saving mechanisms.

Banks in El Salvador have also devised various ways to extend mortgage loans to migrants in their home country. Some banks are even offering microcredit lines at preferential rates with no further requirement than the proof of remittances received.

Clearly, making more progress in terms of encouraging financial saving may require more than just opening bank accounts. It will require 
complementary interventions focusing on financial education, building trust in financial institutions, and innovation in product design. The success of these policies in terms of creating and sustaining a culture of formal savings will also depend on the functioning of the entire financial ecosystem.

\section{Banking-The Old Fashioned Way}

Technological and financial innovations like simplified accounts can make it easier to open bank accounts, but the availability of a bank branch, where potential customers can make regular deposits and withdrawals, can also encourage saving. Bruhn and Love (2014) show that the almost overnight expansion of Banco Azteca to become the second largest network of branches in Mexico inspired a sudden boom in saving accounts in the municipalities in which Banco Azteca began operations. Similarly, expansion of the state-owned financial institution, Patronato del Ahorro Nacional, in 1993 increased households' saving rate by over 3 percentage points (from around 14 percent to 17 percent), with bigger surges among poorer households (Aportela, 1999).

The problem is that opening up physical branches, particularly in remote locations, can be very costly for financial institutions. Remote locations are by definition likely to bring in relatively few customers.

Over the years, policymakers have tried to create incentives for financial institutions to reach relatively small and distant communities. In Latin America, the deployment of physical infrastructure has relied heavily on the expansion of public banks. In Mexico, for instance, BANSEFI started a US $\$ 150$ million program in 2002 to strengthen the efficiency and outreach capacity of 19 small savings and credit institutions. A core aspect of the program was the development of an information technology system linking 180 offices of these institutions and BANSEFI's own 551 branches (Taber, 2004). This allowed BANSEFI to increase its coverage from 28 percent of municipalities in 2006 to 98 percent in 2013. In Chile, approximately 21 percent of the branches of Banco Estado are in regions with fewer than 1 million inhabitants. In Colombia, over 24 percent of the branches of Banco Agrario are located in cities with less than 1 million inhabitants.

India undertook one of the largest branch expansion programs in the world in the 1980s. To obtain a license to open a branch in a location that already had one or more branches (a "banked location"), a bank had to open branches in four eligible "unbanked locations." This 
process had a sizable positive impact on mobilizing saving and accumulating capital (Burgess and Pande, 2005), although it is unclear whether these benefits outweighed the very significant costs of the decadelong strategy.

Creating incentives for private institutions to open more branches can be even more challenging, and potentially expensive. High income inequality (as discussed in Chapter 3) and limited competition in the financial industry can reinforce this lack of incentives. Therefore, governments should have a clear diagnosis of the reasons for the low physical penetration and weigh all the policy options, including direct subsidies and changes to competition policy, where necessary.

\section{More than Brick-and-Mortar Banking}

A complementary approach to opening brick-and-mortar branches is promoting the use of alternative banking channels, such as agent networks. This form of branchless banking has the potential to promote financial saving by providing services at a lower cost, and with greater flexibility, than traditional banking to a broader customer base.

Bank agents are nonfinancial retailers that offer basic financial services under the name of a financial services provider. They are access points to the formal financial system. Policymakers around the world are searching for new ways to offer saving instruments through branchless channels. In Kenya, for example, the Retirement Benefits Authority (RBA) introduced a retirement saving plan in 2009 for informal workers, who could contribute through mobile money providers. The plan succeeded in promoting formal saving (McKay and Pickens, 2010).

In Latin America, the popularity of bank agents has increased as regulatory frameworks have adapted, and as information technologies have allowed the massive use of portable devices (mobile phones, portable terminals) to carry out financial transactions. The region has the highest number of "pure" bank agents per 100,000 inhabitants (bank agents that directly link the customer with the financial institution without an e-money issuer or a telecom company mediating this relationship). Brazil leads the expansion of agent networks, with 208 agents per 100,000 inhabitants (see Table 11.2). The path for Brazil to become the regional leader was cleared in 1999 with a central bank resolution that instituted correspondente (correspondent) relationships, which allow banks to establish agreements with nonbanking firms to provide financial and 
payment services. With the proliferation of agents in Brazil, the financial industry has been able to enter into increasingly more remote and less densely populated areas (Assunção, 2013).

In Chile, bank agents became popular even before appropriate regulation was put in place in 2010. A pilot program launched in 2005 by the state-owned Banco Estado was the precursor of the current Chilean model, which now has 118 agents per 100,000 inhabitants. Colombia introduced regulation for bank agents in 2006 and launched an ambitious government subsidy program in 2007, under which banks would bid to place their agents in certain municipalities previously chosen by a government agency (Banca de Oportunidades). Households and small businesses were 13 percent and 8 percent more likely, respectively, to use formal savings products in municipalities covered by the program

\section{Table 11.2 Coverage of Bank Agents, Select Latin American Countries and Various Regions}

\begin{tabular}{lcc}
\hline & $\begin{array}{c}\text { Agents per 100,000 } \\
\text { inhabitants }\end{array}$ & $\begin{array}{c}\text { Agents per 1000 } \\
\text { sq km }\end{array}$ \\
\hline Brazil & 208.2 & 44.1 \\
Colombia & 115.3 & 43.1 \\
Chile & 118.0 & 23.9 \\
Peru & 69.2 & 14.8 \\
Ecuador & 49.2 & 27.3 \\
Guatemala & 43.7 & 54.7 \\
Mexico & 22.7 & 12.9 \\
Venezuela & 10.3 & 3.1 \\
Paraguay & 5.7 & 0.9 \\
\hline El Salvador & 1.0 & 2.7 \\
Bolivia & 0.8 & 0.1 \\
\hline East Asia and Pacific & 32.3 & 36.3 \\
Eastern Europe and Central Asia & 25.0 & 2.7 \\
Latin America and the Caribbean & 100.7 & 26.8 \\
Middle East and North Africa & 50.2 & 32.8 \\
South Asia & 57.6 & 221.9 \\
Sub-Saharan Africa & 5.2 & 3.0 \\
\hline Developed countries & 18.8 & 3.7 \\
\hline
\end{tabular}

Source: Authors' calculations based on Cámara, Tuesta and Urbiola (2015) and the World Development Indicators.

Note: Developed countries include Australia, Canada, New Zealand, United States and Western Europe. Data for regions correspond to 2014; data for individual countries are for 2013. 
compared to peer individuals in a control group of municipalities (Econometría and SEI, 2011).

Despite progress, important gaps remain and there is ample room for improvement. First, Latin America is very large, and while the region ranks first in terms of agents per 100,000 habitants, it has relatively few bank agents per 1,000 square kilometers compared to other developing regions. Thus, many geographical areas remain without coverage. Second, the pervasive use of cash in the region makes transactions through bank agents expensive. Given the risks and costs of carrying cash over long distances, banks that operate networks need physical branches near the agent's area of influence. This in turn suggests that most agent networks must be operated by banks with an already existing, large brick-and-mortar branch network.

To solve these problems, policymakers should encourage the entry of independent agent networks. They can reach more customers, particularly in remote areas, and also promote competition among financial institutions (de Olloqui, Andrade, and Herrera, 2015). Furthermore, expanding the range of services that agents can provide to include retail payments and remittances can also help financial institutions achieve a sustainable scale of operation.

\section{Dialing up Technology}

The widespread adoption of mobile technologies can also promote branchless banking. ${ }^{8}$ Financial accounts associated with a mobile phone number, or operated exclusively through mobile phones, are usually simpler to set up and cheaper to use than standard bank accounts. Depending on the country's specific regulations, mobile accounts typically do not require a minimum deposit or a minimum balance. They do not charge an administrative fee, and they do not charge users for a certain number of transactions per month (cash withdrawals, balance inquiries).

Mobile technology helps overcome one of the main obstacles currently facing bank agent networks in Latin America: the need to operate groups of agents through nearby branches. However, a parallel platform for financial services does have transaction costs associated with the high use of cash in the region. Potential customers that use cash for their everyday transactions have to convert that cash into electronic deposits and vice-versa (i.e., a process known as "cash-in-cash-out", or CICO). Thus, for mobile technologies to effectively complement bank agents, 
the costs of $\mathrm{CICO}$ have to decline. Doing so requires a combination of specialization in the provision of $\mathrm{CICO}$ services (for example, through specialized providers that can connect final users with multiple financial institutions) and encouraging less use of cash for daily transactions (so that $\mathrm{CICO}$ is less frequent).

The good news is that mobile phone penetration in Latin America and the Caribbean is high by international standards: unique subscriber penetration in the region was 52 percent in 2014-the highest among developing regions (Almazán and Frydrych, 2015). However, Latin America still lags behind other developing regions in terms of using mobile technologies for financial services. With a few exceptions, such as Mexico, in most countries in the region, the ownership of mobile accounts is less than what would be expected given the penetration of mobile phone subscriptions, the physical coverage of the financial system, and the fraction of people residing in remote areas. More importantly, in most countries, the use of such accounts to receive money (the most prevalent use of mobile accounts everywhere) is less than what would be expected given the penetration of mobile accounts (see Figure 11.7).

As shown in Figure 11.7, more people in Mexico have a mobile account and use it than would be expected given the penetration of mobile telephony and the current physical coverage of the banking system. An important contributing factor is that in 2012 Mexico became the first country in the world to ease the anti-money laundering regulations for bank accounts linked to mobile phones, while still complying with the new recommendations of GAFI (Money Laundering Financial Action Group) on low-risk products (Alonso et al., 2013).

Colombia is a noteworthy case because it still has low penetration of mobile accounts, but it ranks among the highest in the region in terms of regulation of digital financial services according to the 2015 Global Microscope.

In Peru, the regulator introduced a simplified process for opening financial products in 2011. In 2012, an electronic money law was passed that creates a new license for specialized operators, allowing nonfinancial service providers to enter, and thus increasing competition. As a result, in a rather unprecedented coordination effort, the Peruvian bankers' association, ASBANC, is building a single platform that can be used by all parties involved in providing these services, including telecommunication companies. 


\section{Figure 11.7 Penetration and Use of Mobile Accounts}

a. Mobile accounts (as percentage of population over 15)

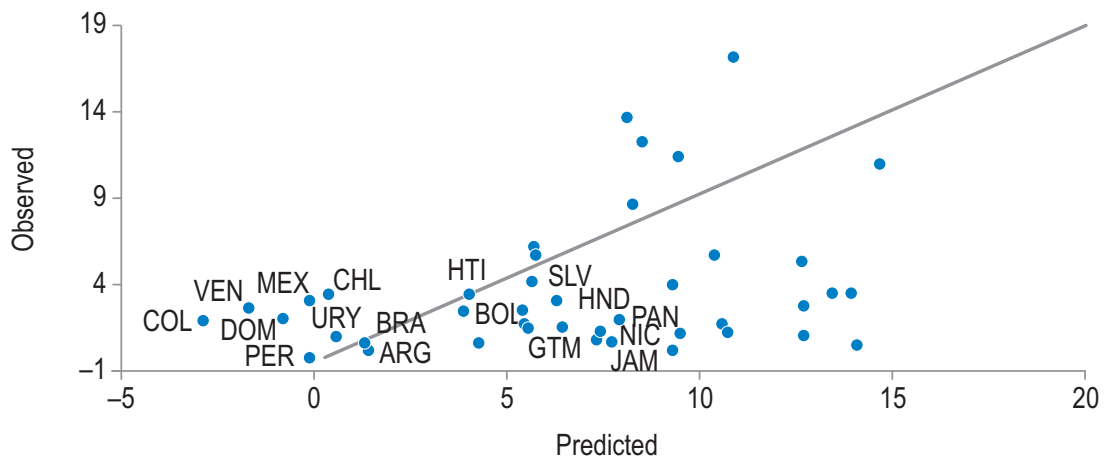

b. Received domestic remittances through a mobile phone (as percentage of recipients of remittances over 15)

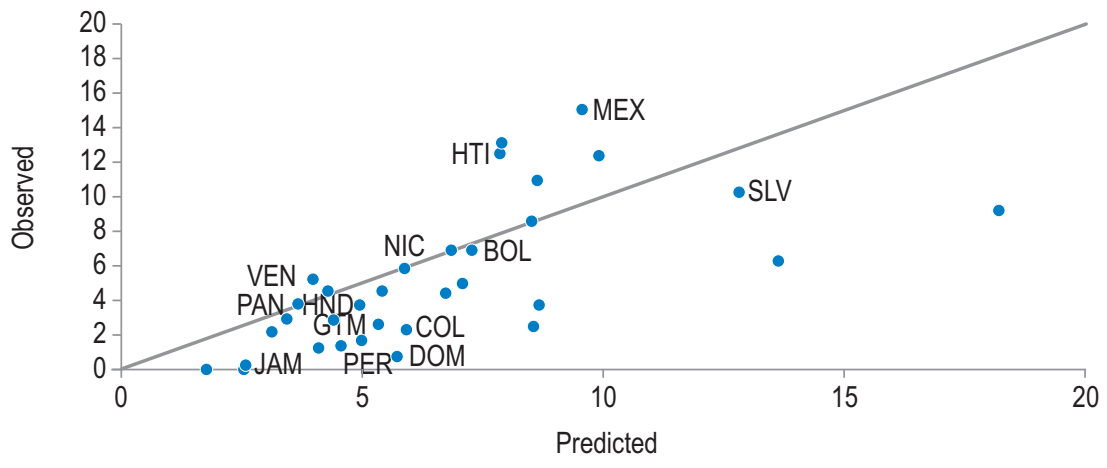

Source: Authors' calculations based on World Bank (2014b) and World Develompent Indicators database (World Bank).

Note: The left panel plots the observed values for the fraction of adults with a mobile account (penetration) against those predicted by a linear regression using mobile phone penetration, bank branch and ATM per $\mathrm{km} 2$ and urbanization rate. The predictions in the right panel are for the use of mobile accounts (receiving domestic transfers) with mobile account penetration as sole regressor. Countries in sample: Argentina, Benin, Bolivia, Botswanaa, Brazil, Burkina Faso, Burundi, Cameroon, Chad, Chile, Colombia, Democratic Republic of the Congo, Dominican Republic, El Salvador, Gabon, Ghana, Guatemala, Guinea, Haiti, Honduras, Indonesia, Jamaica, Kenyaa, Madagascar, Malawi, Malaysia, Mali, Mauritius, Mexico, Namibia, Nicaragua, Niger, Nigeria, Panama, Peru, Republic of the Congo, Rwanda, Senegal, South Africa, Tanzaniaa, Thailand, Togo, Ugandaa, Uruguay, Venezuela, Zambia and Zimbabwe. ${ }^{\text {a }}$

a These countries are in the sample but are not shown; their predicted or observed values are greater than 20 percent.

In Paraguay, a novel feature of the regulation is that balances on mobile accounts that have been inactive for 90 days or more must be automatically transferred to a savings account at a formal financial institution.

Further policy interventions should support the development of the market for mobile banking specifically and the digital finance environment 
more generally. Such policies should build upon past achievements and current market conditions. Thus, they may differ from one country to another. Andrade and Mas (2015) describe at least five different scenarios under which the market for digital finance should flourish. The different policy avenues should be contingent on issues such as whether a big player is already taking most of the market and asymmetric regulation is required (as in Kenya) or whether a public agency is already working on reducing the use of cash among savers.

Specific policies can add dynamism to the digital finance market in the short term. For instance, they can address the need for specialized providers to enter the market (de Olloqui, Andrade, and Herrera, 2015). This, in turn, requires developing appropriate regulation for the use of existing mobile infrastructure by entrants. Likewise, promoting interoperability among platforms (so that users can make transfers to and from accounts at different mobile finance providers and between platforms and traditional bank providers) is a key element in the effort to increase the scale of operations and lower service costs. More flexible and complex financial services through mobile phones will also require enhancing mobile network capabilities.

\section{Financial Saving beyond Banking}

Latin America has a bank-centered financial system and banks and capital markets are complements rather than substitutes in financial markets (see Chapter 3). Therefore, policies that encourage the growth of bankcentered financial systems may also support the development of capital markets in the region, even though the exact way and pace at which each grows will vary according to the idiosyncrasies of each country.

However, specific aspects related to capital markets can help break the vicious circle of low saving and inefficient use of existing savings (shown in Figure 11.1).

One of these is pension funds, which are becoming increasingly important asset managers in many countries across the region (Bebczuk, 2015b). Assets managed by private pension systems exceed 50 percent of GDP in Chile (an early reformer). They are also already high in Colombia, Mexico, and Peru, and are projected to continue growing. While these sums are still low compared to Advanced Economies, they are nonetheless sizable. This pool of capital is potentially important for funding productive investments like infrastructure because pension 
funds accumulate long-term savings in domestic currency. However, the funds accumulated in pension funds are not always invested efficiently. For example, the risk profile of infrastructure investment projects is attractive for investors with long-term horizons, such as pension funds (see Chapter 4). However, on average, only about 2 percent of the total portfolio of pension funds in Latin America and the Caribbean is invested directly in infrastructure projects. This compares to between 5 and 7 percent of such investment portfolios in Australia and Canada. Conversely, a relatively high share of pension fund portfolios is invested in government bonds in Latin America and the Caribbean. In some countries, the problem is compounded by the fact that the lack of alternative financing options increases governments' temptation to capture the resources of institutional investors in order to cover their own current financing needs. ${ }^{9}$ To reverse this pattern, two changes are needed. First, the supply of "investible assets" must expand through regulatory and institutional reforms that turn infrastructure into an asset class (see Chapter 4). Second, countries in the region should review pension fund investment allocation rules and regulations to enable and promote more investment diversification (see Chapter 7).

In addition, underdeveloped insurance markets in the region limit the opportunities for portfolio managers of pension funds and other asset managers to improve the risk-return profile of investment projects. A case in point is the collapse of Monoline insurance, which provided insurance to infrastructure bonds. This has severely limited the opportunities for prospective investors to mitigate risk. Deepening and strengthening insurance markets through regulatory and institutional reforms is yet another way to promote the development of capital markets in the region.

\section{Creating a Virtuous Circle}

Saving is low in Latin America and the Caribbean, and only a small fraction of the savings generated is channeled to the rest of the economy via an efficient financial system. Financial systems across the region are small and inefficient. Encouraging efficient financial saving requires concerted efforts on the demand and supply sides of financial services.

To expand the customer base of financial services, financial inclusion policies should be upgraded from the traditional focus on opening 
bank accounts toward an approach that encourages the use of the formal financial system as the main saving vehicle. Encouraging more formal financial saving, however, does not guarantee the efficient use of those savings. The resources must be channeled to enterprises with higher productive potential. Financial inclusion policies must be coupled with reforms that reduce distortions in financial markets to ensure that resources flow to the most productive-or potentially productive-uses.

Latin America and the Caribbean is caught in a vicious circle-but there is an alternative. The option is a virtuous circle (Figure 11.2) that begins with a culture of saving that generates higher savings for both firms and individuals to invest. The larger supply of loanable funds feeds the growth of the financial system, which can then lower its costs for lenders and borrowers alike. Lower costs are accompanied by regulatory reforms that strengthen property rights and expand credit information. Capital is allocated more efficiently to productive firms that grow, employ more workers in the formal economy, and feed overall economic growth. Gainfully employed people in formal jobs earn enough to invest in their own and their children's health and education and prepare for their retirement. A healthier, more educated workforce and a financial

Figure 11.8 The Virtuous Circle of High Saving and Efficient Financial Intermediation

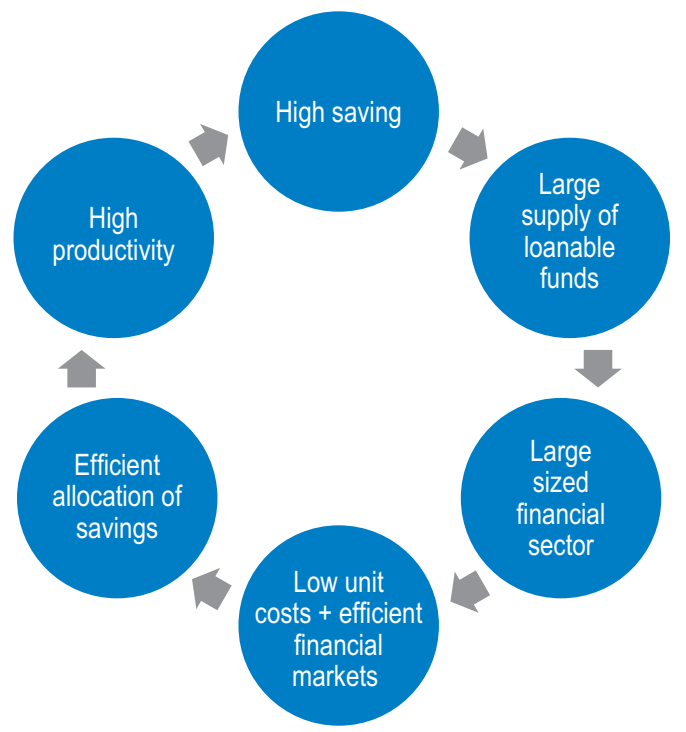

Source: Authors' elaboration. 
system capable of supporting the investment needs of an expanding productive base fuel productivity. Higher productivity provides greater returns to investment and saving and, thus, encourages even more and better saving.

Despite the financial deregulation and reforms of recent decades, financial systems in Latin America and the Caribbean remain very shallow by international standards. Undeniably, the region has made notable progress in recent years. However, the region is still far from breaking into the virtuous circle. Fixing the system is not an easy task, but it is an important one. If Latin America and the Caribbean hopes to grow and prosper in a sustainable and equitable manner, its governments and citizens must learn how to generate and use saving for development. 


\section{Notes}

1 The aggregate marginal product of capital in the region is below that of Advanced Economies and Emerging Asia, according to calculations using a methodology that corrects marginal products for the effect of the relative price of capital (Caselli and Feyrer, 2007). For the median country in Latin America, the estimated marginal product of capital is 8.4 percent, while it is 11.1 percent in Advanced Economies and 9.3 percent in Emerging Asia.

2 In addition to having to deal with financial market frictions and competition issues, firms in the region may be inherently more volatile and risky, which could justify the persistence of high interest rate spreads. While this issue has not been properly researched, the relatively high profitability of the financial industry in Latin America and the Caribbean does not appear consistent with this hypothesis.

3 Coverage is measured as the percent of adults covered by the credit bureau. Research by Martínez Pería and Singh (2014) suggests that after the introduction of a credit bureau-but not a credit registryfirms can access loans from banks more easily, at lower cost, and at longer maturities. As predicted by theory, the effects are more pronounced for smaller firms, which tend to be less transparent and less experienced.

4 A comprehensive review of the consequences of weak property rights in financial intermediation can be found in Fernández and Tamayo (forthcoming).

5 Economies of scale can also be achieved by coordinating suppliers. A clear example of the cost structure under which financial institutions operate is their use of network-specific technologies. Physical branches, automated teller machines (ATMs), and mobile phone applications are often developed to function for a single institution or a small set of providers. Expanding the network to other suppliers (to increase the volume of users) would reduce unit costs; however, that would require coordination so that all providers/users would contribute their fair share to setting up and maintaining the system. The lack of coordination is a market failure that may warrant policy intervention.

6 Among many other things, the Global Microscope asks local experts to grade the ease with which saving products may be offered based on existing practices and regulations such as interest rate restrictions and account opening requirements. See : www.eiu.com/microscope2015 
7 In Latin America and the Caribbean, personal remittances received amount to about 6 percent of GDP, on average. For some countries, remittances (as a percent of GDP) are significantly higher (World Development Indicators Database)

8 A comprehensive review of some of the issues covered in this section can be found in Chong (2011).

9 Becerra, Cavallo, and Scartascini (2012) show that, in countries where governments have lower state capabilities, governments are more likely to direct credit to finance their own operations, thereby curtailing credit to the private sector. attribution to the Inter-American Development Bank (IDB) and for any non-commercial purpose. No derivative work is allowed.

Any dispute related to the use of the works of the IDB that cannot be settled amicably shall be submitted to arbitration pursuant to the UNCITRAL rules. The use of the IDB's name for any purpose other than for attribution, and the use of IDB's logo shall be subject to a separate written license agreement between the IDB and the user and is not authorized as part of this CC-IGO license. Note that the link provided above includes additional terms and conditions of the license.

The images or other third party material in this chapter are included in the work's Creative Commons license, unless indicated otherwise in the credit line; if such material is not included in the work's Creative Commons license and the respective action is not permitted by statutory regulation, users will need to obtain permission from the license holder to duplicate, adapt or reproduce the material. 